(Uniwersytet Zielonogórski, e-mail: marian.bugajski@neostrada.pl)

ORCID: 0000-0002-4471-5353

\title{
TOMASZA SZUMSKIEGO POGLĄDY NORMATYWNE W DZIELE DOKEADNA NAUKA JĘZYKA I STYLU POLSKIEGO
}

W 1809 roku ukazała się Dokładna nauka języka i stylu polskiego. Łączył w niej autor ideę naukową i dydaktyczną $z$ dobrem społecznym, ponieważ „jest powinnością każdego człowieka starać się być użytecznym temu krajowi, w którym się żyje”, „a szczęśliwość narodu” zależy od powszechnego oświecenia, od umiejętności czytania i pisania, od doskonałości języka ojczystego. ${ }^{1}$ Pisał:

Znali się też Polacy na prawdziwej nauk wartości, kochali je szczerze, protegowali i od wykorzenienia ich przez tłumy hord dzikich w swoim i obcym kraju pod Wiedniem $z$ wiekopomna sława męstwa obronili. ${ }^{2}$

Dokładna nauka... jest to dzieło mniej znane i według słów Zenona Klemensiewicza mniej ważne, ${ }^{3}$ natomiast Stanisław Urbańczyk stwierdził, że jest to gramatyka „na niezłym poziomie”, jej wykład jest „dość szczegółowy”, zawiera „wiele słusznych spostrzeżen”" ${ }^{4}$ Moim zdaniem szczególnie ważne są spostrzeżenia dotyczące zagadnień normatywnych, ponieważ gramatyka Tomasza Szumskiego ma wyraźnie normatywny, czasami przesadnie dydaktyczny, charakter. Pod tym względem wyróżnia się na tle innych opracowań.

Jak większość ówczesnych prac językoznawczych, jest traktowana przez badaczy jako gramatyka (podręcznik do gramatyki). Rzeczywiście, jest to podręcznik przedstawiający wiedzę o gramatyce polskiej, jednak daleko - szczególnie część druga - poza gramatykę wykracza, gdyż T. Szumski nie tylko opisywał zasady budowy języka, ale starał się uczyć

1 T. Szumski, Dokładna nauka języka i stylu polskiego, Poznań 1809, Przedmowa, strony nieliczbowane.

2 Inwokacja, Prześwietna Izbo Edukacyjna, strony nieliczbowane. s. 671 .

3 Z. Klemensiewicz, Historia języka polskiego, wyd. IX, Warszawa 2015,

4 S. Urbańczyk, Dwieście lat polskiego językoznawstwa, Kraków 1993, s. 18, 19. 
reguł jego użycia, ${ }^{5}$ gdyż „...lepiej jest popełnić omyłkę jaka gramatyczną (...) niż kilka lat nad samą gramatyka przepędzić, wiedzieć na pamięć wszystkie prawidła, a nie umieć żadnej rzeczy ułożyć na piśmie". ${ }^{6}$

W pierwszej (opracowanej metoda katechetyczną) części oprócz wstępu sa to, mówiąc słowami autora: początkownia - nauka o początkach języka; odmiennia - nauka o podziale wyrazów na części mowy, o ich odmianie przez stopniowanie, przypadkowanie i czasowanie, szykownia - nauka o szykowaniu wyrazów; wyrazotwornia - nauka o tworzeniu wyrazów. Swoistym dodatkiem do tej części jest Deklamatoryka $z$ rozmaitymi dobrymi wierszami stosownymi do ćwiczenia się $w$ dobrym deklamowaniu oraz do ukształcenia szlachetnego sposobu myślenia $w$ młodzieży. W gramatyce pomieszczono też dodatek metodyczny Krótkie nauki o dawaniu nauki języka polskiego, dodatek zawierajacy przykłady zła polszczyzna pisane, które uczniowie poprawiać powinni oraz Zbiór wyrazów gramatycznych w obadwóch częściach zawartych, czyli wykaz terminów $z$ łacińskimi odpowiednikami.

Druga część zawiera poprzedzona przedmowa Sztuke pisania w rozmaitych materiach uczonych, listownych i urzędowych dla użytku młodzieży. Tu z kolei w pierwszej części jest teoria stylu, w drugiej - łatwiejsze materie uczone, w trzeciej - trudniejsze materie uczone, w czwartej-prawidła i wzory rozmaitych biletów i listów, w piątej - prawidła i wzory rozmaitych pism urzędowych. Całość stanowi systematyczny wykład umiejętności i sprawności językowej podporzadkowany zasadom prawdziwej i dobrej polszczyzny, która przeciwstawia czterem „prowincjonalizmom” (gwarom, dialektom). Sa to prowincjonalizmy: litewski, krakowski, mazowiecki, śląski. Prawdziwej polszczyzny trzeba się uczyć z dzieł uczonych, prawdziwie oświeconych Polaków. ${ }^{8}$

Definiuje Tomasz Szumski gramatykę jako „...porządny zbiór prawideł języka, czyli mowy ludzkiej ustnej i pisanej”. Język zaś według niego „... jest to zbiór gestów i wyrazów przez ludzi dla zrozumienia się wymyślonych". ${ }^{9}$ Wobec tego dzieli język na głosowy i gestowy. Gramatyka dotyczy tylko głosowego, który jest wymyślony przez ludzi, a przez to zróżnicowany w odróżnieniu od gestowego będącego językiem przyrodzonym wszystkim ludziom. ${ }^{10}$ Wszystkie gesta maja swoje znaczenie i trzeba wiedzieć, co one znaczą i umieć je „udawać”. Pojawiaja się więc w dziele T. Szumskiego zagadnienia tzw. dziś komunikowania niewerbalnego i tzw. mowy ciała.

5 Por. S. Urbańczyk, op. cit., s. 19.

6 T. Szumski, Dokładna nauka..., Przedmowa, strony nieliczbowane.

7 S. Urbańczyk [op. cit., s. 18] pisze, że T. Szumski „posłużył się metoda pytań i odpowiedzi”. Dotyczy to jednak tylko części I.

8 S. 24.

9 T. Szumski, Dokładna nauka języka $i$ stylu polskiego, op. cit., cz. 1., s. 240 .

10 T. Szumski, op. cit., s. 2-3. 
Gramatykę zgodnie $z$ ówczesnym stanem wiedzy dzieli na powszechną (ogólna), która miałaby zawierać prawidła wszystkich języków, i szczegółowa obejmująca to, co właściwe tylko jednemu językowi. W Przedmowie ${ }^{11}$ powiada, że korzystał $z$ licznych polskich i cudzoziemskich opracowań, których autorów jednak nie wymienia. Nie wymienia też nazwiska Onufrego Kopczyńskiego, przywołuje natomiast jego dzieło: „... była mi największa pomoca Gramatyka Narodowa...", zastrzegając, że nie bierze pod uwagę prawideł języka łacińskiego. ${ }^{12}$

Wyróżnia T. Szumski trzy stopnie znajomości języka głosowego: niska, wyższą i najwyższą. Pierwsza $z$ nich jest właściwa ludziom prostym, ma polegać na praktycznej znajomości wyrazów i stosowaniu ich w rozmowach potocznych - bez znajomości gramatyki.

Wyższa umiejętność to nie tylko rozumienie wyrazów i ich znajomość praktyczna, ale także umiejętność czytania i pisania w „lekkich materiach", czyli niezbędnych obywatelowi w codziennym życiu. Wymienia tu przykładowo „listy, kwity itd.” Chodzi mu zapewne o czynne językowe uczestnictwo w kontaktach oficjalnych i o znajomość zasad pisania listów jako podstawowego i właściwie jedynego sposobu komunikowania się na odległość. Gramatyka jest nauką wyższej umiejętności języka.

Trzeci stopień sprawności miałby być właściwy ludziom uczonym. Oprócz tego, o czym wspomniałem wyżej, miałby polegać na twórczym wykorzystaniu języka do różnych działań naukowych, artystycznych i językowej działalności na wyższym poziomie. Byłaby to między innymi umiejętność tworzenia „rozmaitych memoriałów, dekretów, komedii, rozpraw filozoficznych, kazań, mów itd." ${ }^{13}$ Najwyższej umiejętności języka uczy nauka, która T. Szumski nazywa sztuka pisania w rozmaitych przedmiotach i która dzieli na prozaikę i poetykę. Jak same nazwy wskazuja, pierwsza $z$ nich zajmuje się proza (według autora mową niewiązana), druga zaś „uczy pisać wierszami”. ${ }^{14}$

Wykład prawideł gramatycznych zaczyna T. Szumski od uwag na temat poprawnej wymowy, a zbiera je w sześciu punktach. Nietrudno zauważyć, że miesza przy tym kryteria i warunki, które powinna spełniać dobra wymowa. Mówi więc o higienie narządów mowy i ich budowie anatomicznej oraz brzmieniu głosu, który „... powinien być czysty, gładki, niechrapliwy, przyjemny i zrozumiały". ${ }^{15} \mathrm{Z}$ tekstu można wnioskować, że omówione $\mathrm{w}$ nim zasady nakierowane sa na odbiorcę, autor dba o jego komfort w kontakcie $z$ osobą mówiąca i jednocześnie ma na celu skuteczność wypowiedzi. Dzisiejsze gramatyki takich uwag nie zawieraja, bo nie mieści się to w założeniach metodologicznych.

11 Op. cit., strony nieliczbowane.

12 Jak wiadomo, O. Kopczyński zestawiał gramatykę polską z łacińską.

13 Op. cit., strony nieliczbowane.

14 Op. cit., s. 4.

15 Op. cit., s. 6. 
Dobra wymowa, dobre posługiwanie się językiem jest głównym celem T. Szumskiego. Mówi on na przykład o „dobrej wymowie niektórych głosek”, 16 „wyraźnej wymowie”; 17 wyróżnia dwa rodzaje prawideł składniowych: gramatyczne i retoryczne. Pierwsze $z$ nich objaśnia w następujący sposób:

Podług gramatycznego porządkowania powinien następować: najprzód głównik. Np. Bóg; potem odpowiednik, np. stworzył; a na koniec przedmiotnik, np. wszystko - Bóg stworzył wszystko (...). Myśl mała, tylko 3 albo 2 wyrazy zawierająca, nazywa się okres. Gdy zaś myśl jaka obszerna jest ze wszech stron jaśnie wyrażona, nazywa się period. Każdy okres może być na period przerobiony przez dodanie różnych przysłówków, przymiotników i myśli pobocznych, np. odwieczny i wszechmogący Bóg stworzył w oka mgnieniu wszystkie zwierzęta, rośliny, kruszce i ludzi. ${ }^{18}$

Porzadek retoryczny jest natomiast - powiada T. Szumski - wynikiem dobrego gustu, który można kształtować poprzez czytanie najlepszych autorów, ale

nic gorszego jak gdy kto, nie majacc ani logiki w głowie, ani gustu, chce retorycznie pisać. Pospolicie autor taki wyrazy swoje tak pomiesza, że rzadko kto, albo i nikt nie zrozumie. ${ }^{19}$

Podczas gdy porządkowanie gramatyczne wypowiedzi ma na celu jej jasność i zrozumiałość, porządek retoryczny powinien służyć przyjemności. Mówca tak kształtuje przekaz, aby ten pobudzał wyobraźnię i dawał słuchającemu satysfakcję.

Prawidła słowotwórcze powinny według T. Szumskiego pochodzić $z$ wyrazów dawnych i w miare potrzeb powinny służyć do tworzenia nowych, przy czym twierdzi on, że najpierw tworzono wyrazy konkretne, później zaś abstrakcyjne typu nieśmiertelność, dowcip, umysł. ${ }^{20}$ Zwraca uwagę na konieczność działań słowotwórczych, które powinny podlegać pewnemu porządkowi: wyraz musi znaczyć najprawdziwiej, ${ }^{21}$ co należałoby rozumieć jako zgodność formacji słowotwórczej $z$ jej treścią. Tak więc niewłaściwa forma jest niezwyciężony (taki, którego nie można zwyciężyć), właściwa zaś niezwyciężny, podobnie jak niewidzialny i niewidziany. Neologizm powinien być jasny i zrozumiały, na przykład obcy wyraz egoista powinien zostać zastapiony przez samolubca, który jest lepszy od wyrazów samoistca lub własnomiętnik. Powinien być derywowany od wyrazu polskiego według istniejących już schematów, tak więc „...lepiej jest rękodzielnia niż manufaktura albo fabryka. Lepiej też jest po

\footnotetext{
16 Op. cit., s. 11.

17 Op. cit., s. 13.

18 Op. cit., s. 146.

19 Ibidem.

20 Op. cit., s. 166.

21 Op. cit., s. 176.
} 
polsku działolejnia niż ludwisarnia”. ${ }^{22}$ Jeśli niemożliwe jest utworzenie neologizmu od wyrazu polskiego, należy wziąć za podstawę wyraz „pobratymski”, na przykład czeski albo rosyjski:

Tak np. chcąc ten makaronizm łaciński: adoptacja przepolszczyć, można by z rosyjskiego przyjąć ten wyraz: przysynowienie, albo jeszcze lepiej nowy taki utworzyć przydziecenie (przyjęcie na miejsce dziecka); wszakże tak zostały utworzone wyrazy: pobratanie się, zamęście, ożenienie się itd. ${ }^{23}$

Neologizm powinien być krótki, a przez to łatwy do zapamiętania - tu jako przykłady podaje T. Szumski formy krwiopłyn i płynienie krwi.

Nowe wyrazy zarówno pod względem treści, jak i formy powinny się odróżniać od już istniejących, jak na przykład wspomniany wyżej niezwyciężny i niezwyciężony. Można się domyślać, że w tym wypadku chodzi o odróżnienie form przymiotnikowych od imiesłowowych (por.: wymyślny i wymyślony; wystawny i wystawiony). Proponuje też gramatyk odróżnienie monumentu (wystawionego jakiemuś wielkiemu mężowi) od pomników pomniejszych postaci. Tu według niego odpowiedniejsze byłyby słowa: pomnik lub niezabudek. ${ }^{24}$

Nie należy się trudzić na darmo i tworzyć nowych wyrazów w miejsce już istniejacych, choćby te były wyrazami obcymi. Nie ma więc potrzeby polszczenia takich jednostek jak: cegła, cło, grunt, historia, matematyka, senat itp. Jeśli zaś się zdarzy, że mimo konieczności jakiegoś obcego wyrazu nie da się przetłumaczyć, należy go zaadaptować, nadajac polską „końcówkę”, np. indywidualność. ${ }^{25}$ Zdarza się jednak, że lepiej jest posłużyć się dla jasności wywodu polskimi wyrazami niż obcymi:

„...lepiej jest choć kilką wyrazami prawdziwie polskimi opisać niż cudzoziemski zatrzymać, albo nowy niezrozumiały utworzyć; lepiej jest rzecz przedstawić, przełożyć niż fortragowac" ${ }^{26}$

Waha się więc gramatyk między poczuciem rodzimości a obcości. Nie zajmuje w tej materii wyraźnego stanowiska, stara się zachować obiektywne podejście. Chociaż nie mówi o tym wprost, odnosi się do tzw. narodowego kryterium oceny faktów językowych, przy czym jest to ujęcie zbieżne $z$ późniejszym stanowiskiem Witolda Doroszewskiego, który uważał, że właściwe użycie środków językowych wiąże się z porządkiem myślowym. Wyrazy obce nie sa pożądane w języku nie dlatego, że są obce, ale dlatego że mogą wprowadzać zamęt pojęciowy poprzez czasami bezmyślne stosowanie. Należy popierać żywioł rodzimy w języku, bo jest on

22 Op. cit., s. 173.

23 Op. cit., s. 174.

24 Ibidem.

25 Op. cit., s. 175 .

26 Ibidem. 
bardziej naturalny i przez to bardziej przydatny do formułowania myśli. Nie należy potępiać wyrazów obcych dlatego, że sa obce; jednocześnie należy zachować umiar w ich stosowaniu. ${ }^{27}$

Na koniec odwołuje się do kryterium estetycznego i zaleca, żeby neologizmy miały przyjemne brzmienie; za piękny uważa rzeczownik wyobraźnia utworzony dla zastąienia imaginacji.

To kryterium współistnieje u T. Szumskiego ze wspomnianym wyżej kryterium narodowym. Wynika stąd swoisty zachwyt nad polszczyzna, wyrażony w takich słowach:

Język polski (...) jest w wielu punktach doskonalszy, piękniejszy i bogatszy od innych. Tu zwracam uwagę Współziomków na piękność, rozmaitość i bogactwo głosów języka naszego.. Nie ma żadnego innego języka, któryby się mógł poszczycić jak polski tylą gatunkami głosów średnio- i zupełno otwartych, miękkich, pojedynczych i złożonych; któryby tyle miał samogłosek, tako to czystych, nosowych, otwartych, ściśnionych, krótkich, długich i złożonych $z$ nich dwu- i trzygłosek: język polski ma prawie tyle głosów, ile najdoskonalszy instrument, fortepian. ${ }^{28}$

Jednak, przyznaje gramatyk, „...sa jeszcze piękne głosy w obcych językach, w greckim, francuskim, angielskim i niemieckim (...). ${ }^{29}$

Na uwagę zasługuje wykład „deklamatoryki”, która „...uczy języka gestowego, który się $z$ rozmaitych min, mig i gestów składa”, 30 a jej celem jest wywarcie wrażenia na słuchaczu. Uczy więc T. Szumski odpowiedniego ekspresywnego zachowania, które miałoby wspomagać kod językowy. Dzisiaj mówimy o kodach towarzyszacych, upowszechniły się też terminy mowa ciała i komunikacja niewerbalna. Całość zjawisk, o których mowa, nazywa się zachowaniem jezykowym. ${ }^{31}$

Opis zachowań komunikacyjnych zaczyna od przywitania, dalej mówi T. Szumski o pozycji mówcy (przystojna i przyjemna, niewymuszona), ${ }^{32}$ głos powinien być czysty i wyraźny, bo chrapliwy, powolny i słaby nie może się podobać słuchaczom. Ton - odpowiednio dobrany do treści wypowiedzi. Ważne jest poprawne akcentowanie, które wzmacnia wypowiedź, a niekiedy ma wpływ na jej znaczenie, oraz tempo wymowy - w szczególności należy zwracać uwagę na pauzy. ${ }^{33}$ Całe zachowanie deklamatora (gesty, migi i miny) powinno być stosowne do sytuacji i naturalne, trzeba unikać gestów „nieprzystojnych”, miny zaś ćwiczyć przed lustrem. Jeśli mówca przedstawia jakąś postać, powinien starać się

27 Por. W. Doroszewski, Słownik poprawnej polszczyzny, Warszawa 1976, s. IX.

28 T. Szumski, op. cit., s. 177-178.

29 Op. cit., s. 178.

30 Op. cit., s. 186.

31 Por. M. Bugajski, Językoznawstwo normatywne, Warszawa 1993, tu rozdz. Komunikat językowy i inne formy przekazu, s. 60-67.

32 Op. cit., s. 188.

33 Op. cit., s. 190. 
oddać jej charakter. ${ }^{34}$ Mówić należy naturalnie, gesty, miny i migi powinny dobrze oddawać to, co wyraża on językiem.

Tak np. naturalnie mówiąc o Bogu wznosimy rękę do nieba i oczy pełne uszanowania tamże zwracamy; mówiąc zaś o piekle, wskazujemy palcem w ziemię i patrzymy ze strachem na nią itd.(...) Strzec się jednak należy, aby nie nadto rękami machać i oczami rzucać. ${ }^{35}$

Dalej w kilkunastu punktach omawia gramatyk zachowanie językowe w różnych aktach mowy. Na przykład:

Zapewnienie i obietnica wyrażają się głosem niskim, mocnym, gestem szczerości i podawaniem otwartej ręki. Zaufanie okazujemy skłaniając ciało i mówiąc głosem miłym i szczerym. ${ }^{36}$

Na koniec dodaje zbiór wierszy mający stanowić podstawę ćwiczeń „do deklamowania oraz do ukształcenia (...) szlachetnego charakteru młodzieży”. 37

Drugi tom gramatyki obejmuje sztukę pisania, gdyż znajomość języka nie może polegać tylko na opanowaniu jego gramatyki, trzeba również posiąść praktyczne umiejętności „...trzeba jeszcze $z$ własnej głowy umieć co dobrze ułożyć". ${ }^{38}$ Daje tu także T. Szumski swoisty, metaforyczny wykład metody postępowania. Umiejętność pisania uważa on za sztukę. Gramatyk powinien więc zaczynać nauczanie od zasad budowy języka (chodzi tu przede wszystkim o fleksję i słowotwórstwo). Później, biorąc pod uwagę teorię, powinien nauczać „kopiowania”, czyli odtwarzania i naśladowania. W końcu zaś uczeń powinien tworzyć „oryginały”, które

podług danej teorii krytykuje, i tak gust, uczucie i rozum w uczniu, coraz bardziej zaostrza, a w czym się później sam uczeń, rozważając dzieła klasyczne, do najwyższego stopnia wydoskonalić może. ${ }^{39}$

Tym zasadom podporzadkowane jest całe dzieło T. Szumskiego. ${ }^{40}$ We wstępie do drugiej części dzieła znajdujemy definicję stylu:

To słowo styl, czyli sposób pisania oznacza w ogólności sposób, jak się pisze, czyli jak się myśli własne komu innemu przez pisma udzielaja, a w tym znaczeniu jest styl zły i dobry. W ściślejszym znaczenie rozumie się przez styl ten sposób, którym myśli

34 T. Szumski, op. cit., s. 188-192.

35 Op. cit., s. 192.

36 Op. cit., s. 194.

37 Op. cit., s. 200.

38 T. Szumski, op. cit., Przedmowa - strony nieliczbowane.

39 Ibidem.

40 Całe dzieło jest też osadzone w tradycji gramatyki europejskiej - szczególnie francuskiej i niemieckiej [por.: S. Urbańczyk, op. cit., s. 18, 19]. Nie trzeba dodawać, że stylistyka T. Szumskiego ma Arystotelesowskie podstawy. 
własne przez pismo, albo też ustnie, stosownie do celu i pięknie tak przedstawiamy, ażeby każdy nas $z$ przyjemnością słuchał i dokładnie rozumiał. ${ }^{41}$

Poszczególne gatunki stylu wynikają z zamiaru piszącego. Przykładowo wymienia autor style: powieści i anegdot, kazań i „przepisów moralnych”. Gatunki stylu dzielą się według niego „zewnętrznie i wewnętrznie". ${ }^{42} \mathrm{~W}$ związku $\mathrm{z}$ tym następne partie książki zatytułowane są: O wewnętrzności stylu i O zewnętrzności stylu. Wewnętrzność to inaczej „istota stylu” i tu ze względu na osobę adresata oraz ( $z$ dzisiejszego punktu widzenia) na sytuację komunikacyjną wyróżnia Szumski trzy gatunki: styl poufały, styl średni i styl wysoki. „Wzgląd na zamiar piszącego" każe mu natomiast wyodrębnić sześć zamiarów:

1. rozum nauczać; 2. zabawić wyobraźnią, czyli imaginacją czytelnika; 3. wzbudzić rozmaite wzruszenia umysłu i serca; 4. wszelkim sposobem namówić kogo na rzecz jaką; 5. wzbudzić te uczucia przyjemne, których wysoki stopień w śmiechu się wydaje; 6. największą uwagę wzbudzić i rzecz jaśnie i żywo przedstawić. ${ }^{43}$

Te „zamiary” trzeba rozumieć jako kryteria, na podstawie których ustala następujące style: ${ }^{44} 1$. styl spraw potocznych;45 2 . historyczny, czyli dziejopisarski; 3. dydaktyczny, czyli nauczycielski i filozoficzny; 4. kwiecisty; 5. wzruszajaccy; 6. krasomówczy (krasomówski); 7. komiczny (tu szlachetny komiczny i niższy komiczny); 8. poetyczny. Poza tą klasyfikacją pozostaje styl prozaiczny mający oddziaływać na rozum przeciwstawiony poetycznemu, który oddziałuje na wyobraźnię i dowcip. Niejako mimochodem wspomina T. Szumski o stylu kancelaryjnym (kancellaryjskim), przeciwstawiając go krasomówczemu. ${ }^{46}$

Zewnętrzność zaś to

...forma stylu, dotyka wprawdzie zewnętrzne trefunkowe okoliczności, potrzeba ją jednak znać, aby tym pewniej rozmaitych dosięgnać zamiarów. Wyciaga ${ }^{47}$ ona właściwego sposobu postępowania. Najprzedniejsze formy stylu są: pierwsza forma rozmów, druga forma listów i trzecia forma mów. ${ }^{48}$

41 T. Szumski, op. cit., cz. 2., s. 3.

42 S. 4. Jest to oczywiście nawiązanie do Arystotelesowskich pojęć stosowności wewnętrznej i zewnętrznej. Pierwsza $z$ nich polega na odpowiedniości myśli, rzeczy i słowa, druga zaś na zgodności formułowanej wypowiedzi z możliwościami jej odbioru.

43 T. Szumski, op. cit., cz. 2., s. 5-8.

44 Ibidem, s. 5-9.

45 S. Urbańczyk przypuszcza, że „Szumski być może pierwszy użył wyrazu "potoczny" w odniesieniu do stylu językowego" [Dwieście lat polskiego językoznawstwa, Kraków 1993, s. 19].

46 T. Szumski, op. cit., cz. 2., s. 7.

47 Tu w znaczeniu 'wymaga'.

48 T. Szumski, op. cit., cz. 2., s. 9. Nie rozwija jednak gramatyk tej myśli, trudno więc powiedzieć, dlaczego te formy wyróżnia. 
Jednak tej myśli gramatyk nie rozwija, trudno więc powiedzieć, dlaczego akurat te formy wyróżnia. Prawdopodobnie wynikają one $z$ osobistych doświadczeń i z obserwacji ówczesnych form komunikowania.

Wyróżnia też dwanaście prawideł, które powinny być fundamentem każdego stylu: ${ }^{49} 1$. używanie dobrej polszczyzny, 2. czystość języka, 3. doskonałość języka w gramatycznym, logicznym i retorycznym względzie, 4. zrozumiałość i jasność, 5. stosowność, 6. precyzja, czyli układ rzeczy z celem stosowny, 7. powaga, 8. brzmienie przyjemne, 9. żywość, 10. rozmaitość, 11. nowość, 12. jednostajność. Zastrzega jednak, że nie są one stałe i w zależności od potrzeb, zamiarów i okoliczności moga podlegać modyfikacjom.

Jak widać, posługuje się przy tym pojęciami ważnymi $z$ normatywnego punktu widzenia. Dobra polszczyzna według T. Szumskiego to „... taka, jaka się w najlepszych dziełach znajduje". ${ }^{50}$ Jest to jednocześnie język komunikacji (obcowania) „światłych stanów”. ${ }^{51}$

Takowe to wspaniałe wyrazy, składające piękność i doskonałość języka, maja pierwszeństwo nad różnymi dialektami czyli prowincjonalizmami i wyłączaja je, ponieważ one nie sa powszechnie zrozumiałymi. ${ }^{52}$

Wzorcem miałby zatem być język pisarzy, co mieści się w tradycji lingwistyki normatywnej, już bowiem starożytni Grecy za wzór stawiali język Homera. Także w polskim językoznawstwie w czasach nam bliższych, z czym między innymi wiązało się pojęcie języka literackiego, normę mieli stanowić uznani pisarze,$^{53}$ a o poprawności językowej powinien rozstrzygać między innymi „uzus dobrych autorów”. ${ }^{4}$

Mówi też o czystości języka, która każe się posługiwać wyrazami rodzimymi, wyklucza zaś wszelkie niepotrzebne zapożyczenia. Przeciwstawia jej nieczystość mająca się przejawiać w używaniu archaizmów (zestarzałych słów) lub takich wyrazów, które $z$ jakichkolwiek względów wyszły $z$ użycia oraz prowincjonalizmów, także wyrazów obcych (cudzoziemskich słów) oraz neologizmów (nowszczyzny) ${ }^{55}$ utworzonych niezgodnie $z$ prawidłami i duchem języka. Potępia szczególnie wyrazy francuskie, łacińskie i niemieckie. Zauważmy, że pojęcie czystości języka, chociaż

49 Op. cit., s. 9-17. Nietrudno zauważyć, że prawidła te sa osadzone w Arystotelesowskiej teorii retoryki.

50 Op. cit., s. 10.

51 Ibidem.

52 Ibidem.

53 S. Słoński, Słownik polskich błędów językowych, Warszawa 1947, s. 6.

54 S. Urbańczyk, Hierarchia kryteriów poprawności we współczesnym języku polskim [w:] S. Urbańczyk (red.), Wariancja normy we wspótczesnych słowiańskich językach literackich, Wrocław 1977, s. 79.

55 T. Szumski, op. cit., s. 11. 
nieprecyzyjne i nader często rozumiane intuicyjnie, używane jest jeszcze dzisiaj. .5

Zrozumiałość i jasność (mowy) definiuje w następujący sposób: „mowa ta jest jasną i zrozumiała, w której zawierające się myśli bez trudności zrozumiane i pojęte być moga". ${ }^{57}$ Także te dwa, zazwyczaj razem używane pojęcia, chociaż mało precyzyjne, funkcjonują do dzisiaj, co w dziejach retoryki wiąże się $z$ troska o adresata, który musi odpowiednio wypowiedź zrozumieć i zinterpretować. ${ }^{58}$ Uznaje się, że jasność jest ważnym czynnikiem zrozumiałości, która nie jest jednak pojęciem obiektywnym, gdyż w dużej mierze zależy od indywidualnych predyspozycji odbiorcy. ${ }^{59}$

Stosowność definiuje T. Szumski tak: „przymiot ten zawiera się w najściślejszej zgodzie wyrazów $z$ powszechnymi prawidłami języka i szczególnymi względami piszącego". ${ }^{60}$ I wyjaśnia:

W komedii Bankructwo mówi Kopytnicki, szewczyk, do majstra swego Jaśnie Wielmożny Szewcze. Wyrazy Jaśnie Wielmożny z szewcem są niestosowne; ale ponieważ piszący chce słuchaczów rozśmieszyć, zatem zamiar ten usprawiedliwia ich użycie. ${ }^{61}$

Mówiąc dzisiejszymi słowy, stosowność to sposób komunikowania adekwatny do kontekstu, narzucający pewne zasady zachowania, określający, co należy, a czego nie należy robić. aby

Ze stosownością łączy gramatyk między innymi zwyczaj nakazujący,

...na oznaczenie każdej myśli takiego wyrazu używać, który podług najpowszechniejszego i najlepszego zwyczaju jest najstosowniejszym. Zwyczaj wyłącza wszystkie przestępstwa przeciw powszechnemu używaniu języka... ${ }^{62}$

Mówi też o przyzwoitości i naturalności jako o tych własnościach stylu „....podług których się tak myśli jako i wyrazy do przedmiotu i okoliczności stosują. Jest to sformułowanie niezrozumiale. Niewiele wyjaśnia też takie jego uzupełnienie: „Gdyby kto np. powiedział: grobowiec jego mlekiem i kwiatami obsypywać będa, poznalibyśmy zaraz, iż wyraz obsypywać stosuje się do kwiatów ale nie do mleka". ${ }^{63}$

56 W Encyklopedii wiedzy o języku polskim [red. S. Urbańczyk, Wrocław...1978] zostało zdefiniowane tak: „czystość teoretycznie polega na nieobecności elementów przejętych $z$ obcych języków. W tym sensie jednak języków czystych, tzn. całkowicie pozbawionych obcojęzycznych zapożyczeń, nie ma".

57 T. Szumski, op. cit., s. 11.

58 Por. M. Korolko, Sztuka retoryki, Warszawa 1990, s. 100.

59 Por.: Encyklopedia wiedzy o języku polskim, op. cit.

60 T. Szumski, op. cit., s. 13.

61 Por.: S.P. Morreale, B.H. Spitzberg, J.K. Barge, Komunikacja między ludźmi, Warszawa 2007, s. 67.

62 T. Szumski, op. cit., s. 13.

63 Nawiasem mówiąc, T. Szumski dość nieudolnie posługiwał się istniejącymi terminami. Próbował też terminy tworzyć. 
Warto zwrócić uwagę na pojęcie precyzji, o którym mówi T. Szumski, że jest to „układ rzeczy z celem stosowny”. Jest ono zbliżone do wspólczesnego założenia klarowności wypowiedzi, która jest możliwa, gdy starania nadawcy odpowiadaja umiejętnościom odbiorcy. ${ }^{64}$ Trudno jednak powiedzieć, że sam gramatyk tego założenia przestrzegał, ponieważ dość nieudolnie posługiwał się istniejącymi terminami, próbował też terminy tworzyć, o czym, oprócz wspomnianego wyżej, świadczą też na przykład takie próby definiowania:

Wyraźna pewność. Ta wyciaga, ażeby na każde wyobrażenie tego wyrazu użyć, który najwyraźniejszym i najzrozumialszym jest.

Wyraźność jest przeciwną niepewności. ${ }^{65}$

Powaga to według niego „...zgodność wyrazów ze sposobem myślenia i czucia klas wyższych”; żywość - „...przymiot stylu, przez który na niższe władze rozumowe działać, albo też widoczna zrozumiałość sprawić chcemy"; ${ }^{66}$ brzmienie przyjemne, o którym już wyżej była mowa, to estetyka wypowiedzi, przy tym, jak się wydaje, chodzi mu o wypowiedź ustna. Mówi jeszcze oprócz tego o rozmaitości i nowości stylu. Przez pierwszą $z$ tych cech rozumie „wyrażanie podobnych myśli rozmaitym sposobem;” przez druga „to, co jest nadzwyczajne, albo co jeszcze nie jest zbyt powszednie”. ${ }^{67}$

$\mathrm{Na}$ koniec definiuje jednostajność stylu, czyli taki układ, w którym poszczególne części składają się na jednolitą całość, co w pewnym stopniu można by porównać do dzisiejszej spójności formalno-znaczeniowej tekstu.

Jak wcześniej wspomniano, autor kontynuuje w niej tradycję gramatyk europejskich i polskich:

Zatrudniając się przez lat kilka w Berlinie (...), miałem sposobność poznać, czytać i rozważyć rozmaite cudzoziemskie książki elementarne. Spółziomkowie przeto uczeni, (...), łatwo postrzega, iż ja przy układzie niniejszego pisma korzystałem $z$ rozmaitych najsławniejszych autorów tak ojczystych jako i cudzoziemskich(...). Co się zaś tyczy języka polskiego, przy własnym zastanawianiu się nad nim, była mi największą pomocą Gramatyka Narodowa, której sławnemu i powszechnie szacowanemu Autorowi powinna wdzięczność i uszanowanie tu publicznie oświadczam. ${ }^{68}$

Poglądy normatywne Tomasza Szumskiego można ująć w następujący sposób:

64 Por. na ten temat: M. Bugajski, Pół wieku kultury języka w Polsce, Warszawa 1999, s. 76.

65 T. Szumski, op. cit., s. 14.

66 15. Wymienia też „niższe władze rozumowe”: baczność, wyobraźnia (imaginacja), dowcip, wzruszenie i bystrość umysłu.

67 T. Szumski, op. cit., s. 16.

68 Op. cit., Przedmowa, strony nieliczbowane. 
1. Od teorii gramatycznej (ogólnej i szczegółowej) ważniejsza jest praktyczna znajomość języka, sprawność językowa oraz umiejętność tworzenia tekstów (szczególnie pisanych).

2. Od języka głosowego należy odróżnić język gestowy, w przeciwieństwie do tego pierwszego właściwy wszystkim ludziom. Oba jednak trzeba opanować, bo są ważne w komunikowaniu.

3. Istnieją trzy stopnie znajomości języka głosowego - niski, wyższy i najwyższy. Pierwszy jest właściwy ludziom prostym i służy do kontaktów w rozmowach potocznych, drugi - to także umiejętność czytania i pisania tekstów niezbędnych na co dzień, trzeci jest właściwy ludziom uczonym.

4. Sztuka pisania (prozaika i poetyka) uczy najwyższej umiejętności języka.

5. Dobra polszczyzna, która powinna być wzorowana na języku pisarzy, znajduje się w najlepszych dziełach. Jest to skuteczne posługiwanie się językiem, zapewniające jednocześnie komfort odbiorcy.

6. Prawdziwa i dobra polszczyzna jest przeciwieństwem „prowincjonalizmów" - litewskiego, krakowskiego, mazowieckiego oraz śląskiego i wiąże się $z$ dobrą wymowa.

7. Składnia wypowiedzi podporządkowana jest prawidłom gramatycznym i retorycznym. Pierwsze $z$ nich maja na celu jasność i zrozumiałość, drugie powinny zapewniać odbiorcy przyjemność.

8. Słowotwórstwo powinno się wzorować na wyrazach dawnych, ważne jest ich przyjemne brzmienie i zgodność formacji $z$ jej treścią; neologizm powinien być jasny i zrozumiały, krótki, a przez to łatwy do zapamiętania i operatywny; powinien być tworzony od wyrazu polskiego według istniejących schematów. Nie należy jednak polszczyć wyrazów bez potrzeby.

9. Zamiar piszaccego determinuje poszczególne style. Po raz pierwszy w polskiej literaturze używa T. Szumski pojęcia stylu potocznego (spraw potocznych).

10. Język powinien być czysty. Pojęciu czystości przeciwstawia się nieczystość.

11. Ważnymi cechami języka sa zrozumiałość, jasność i stosowność, determinowana zwyczajem, oraz precyzja.

12. Dość wyraźne (chociaż nie nazywa ich wprost) w poglądach normatywnych gramatyka sa kryteria: historyczne, narodowe, literacko-autorskie i estetyczne. 


\title{
Bibliografia
}

M. Bugajski, Językoznawstwo normatywne, Warszawa 1993.

- Pót wieku kultury języka w Polsce, Warszawa 1999.

W. Doroszewski, Stownik poprawnej polszczyzny, Warszawa 1976.

Z. Klemensiewicz, Historia języka polskiego, wyd. IX, Warszawa 2015.

S.P. Morreale, B.H. Spitzberg, J.K. Barge, Komunikacja między ludźmi, Warszawa 2007.

S. Słoński, Słownik polskich błędów językowych, Warszawa 1947.

T. Szumski, Dokładna nauka języka i stylu polskiego, Poznań 1809.

S. Urbańczyk, Dwieście lat polskiego językoznawstwa, Kraków 1993.

- (red.), Encyklopedia wiedzy o języku polskim, Wrocław... 1978.

- Hierarchia kryteriów poprawności we współczesnym jezzyku polskim [w:] S. Urbańczyk (red.), Wariancja normy we współczesnych słowiańskich językach literackich, Wrocław 1977, s. 75-83.

\section{Tomasz Szumski's prescriptive views in the work Dokładna nauka języka i stylu polskiego (Learning the Polish language and style thoroughly)}

\author{
Summary
}

The aim of this paper is to present Tomasz Szumski's prescriptive views.

Dokładna nauka jezzyka i stylu polskiego (Learning the Polish language and style thoroughly) is not a highly popular work, yet one deserving attention as it combines a grammatical description of the Polish language with the rules governing its use, including a lecture on communication behaviours. It is a systematic and a clearly prescriptive lecture of good Polish, where the author distinguishes three levels of command of the language. It includes not only a description of grammatical rules but also guidance regarding proper pronunciation, text construction and delivery. The rules formulated by T. Szumski are expressly oriented towards addressees with the aim to make them feel comfortable; they are also conditions of an effective utterance/statement. The study is embedded in the European grammatical and rhetorical tradition. Historical, national, literary, and aesthetic criteria, although unnamed directly, are clear in the author's thinking about the language.

Keywords: history of language - language teaching - language culture - language communication - language norm assessment criteria - Tomasz Szumski.

Trans. Monika Czarnecka 